\title{
REVERSE LOGISTICS AND 3PL IN THE CZECH REPUBLIC
}

\author{
A. Klapalová
}

\author{
Received: August 16, 2012
}

\begin{abstract}
KLAPALOVÁ, A.: Reverse logistics and 3PL in the Czech Republic. Acta univ. agric. et silvic. Mendel. Brun., 2012, LX, No. 7, pp. 163-170

The paper is focused the results of survey investigating the utilization of services of the so called 3PL (third party logistics) or in other words outsourcing of reverse logistics activities (RL) in the context of their strategic versus operative or ad hoc management of RL and in relation to various benefits seeking and gaining within the frame of RL management. The exploratory analysis tries to answer the basic research question whether companies strategically managing reverse flows (RF) use services of 3PL more often compared to companies with ad hoc or operative management and what is the role of costs versus benefits in the context of outsourcing of RL activities. The survey was realized among 150 Czech small, middle and big companies from several industries and the size and type of industry are two other contextual factors related to outsourcing decisions. Results show statistically significant relationship between character of planning hierarchy and number of activities performed by 3PL, where companies that plan RF strategically, employ 3PL more often. The findings indicate also differences between the companies which plan RF strategically and those which plan RF only on tactical and operational level (Sig. (1-tailed) $=0.033$ ) and those that do not plan at all (in comparison to those that plan on strategic level - Sig. (1-tailed) $=0.123$ ) when analyzing the types of RL activities. The survey also shows that companies which outsource more RL activities ( 3 and more), perceive less financial benefits than nonfinancial benefits. Significant dependence was detected between the size of company and number of both benefits perceived with RF management. This finding can stand for the fact, that in bigger companies more commitment of managers and employees is devoted to RF. Very important result shows that activities which are outsourced distinctly more by the companies planning RL strategically belong to the activities creating higher value for companies. The paper contributes to a better understanding of present knowledge targeted at RF management practices and offers the first existing knowledge of the utilization of 3PL for RL practices in the Czech Republic.
\end{abstract}

reverse logistics, activities, management, benefits, 3PL, outsourcing

Since the seventies of twentieth century the concept of reverse flows (also as RF in the text) as a scientific term emerged in literature (De Brito, 2003) although enterprises had to be interested in some aspects of managing any items which 'returns' to the company since the beginning of entrepreneurship. The very much same we can say about outsourcing. For instance Kakabadse and Kakabadse (2002) refer history of "conscious" and documented outsourcing managed processes to Old Romans, however as the theoretic concept it has started to be developed in the late seventieth and beginning of eighties of the twentieth century.
In this paper "reverse flows" is used as term of all those flows of raw materials, in-process inventory, finished goods and related information from the point of consumption to the point of origin for the purpose of recapturing value or proper disposal (Rogers and Tibben-Lembke, $1999 ;$ p. 2). As the synonymous other concepts in the literature can be found that may be used interchangeable to some extent (returns, backwards flows and for managerial processes the most typical concepts are reverse logistics (also RL in the text) and supply chain loop). Reverse flows origin both in the internal as well as external environment of the 
company and they are often subject of interest of logistics or supply chain management.

Any decision to outsource is a long-term strategic decision and this concerns decisions of RL as well (De Brito, 2003), so managers should know and understand the benefits or threats or advantages and disadvantages of outsourcing very well. Strategically managed RL activities can be more effective and can lead to sustainable competitive advantage (Mollenkopf and Closs, 2005) and outsourcing can be one of enabling factors (Ordoobadi, 2009). Despite this fact many companies still treat RF as non-value-generating areas of entrepreneurship (Mukhopadhyay and Setaputra, 2006) as well as they connect outsourcing with simple purchasing of just cost-reducing or missing activities (Gilley and Rasheed, 2000).

Research on many aspects of 3PL engagement in RL is still limited (Ordoobadi, 2009; Serrato et al., 2004; Cheng and Lee, 2010). The aim of this paper is therefore to present results of one survey and so to contribute to the knowledge regarding RL outsourcing. The major aim is to find answers to three basic questions, namely: 1. Is there any link between level of planning involvement and outsourcing of RL activities?; 2. Do companies that engage 3PL for RL activities perceive other benefits compared to those which are less active in RL outsourcing?; and 3. Are there any differences among companies that outsource more or less RL activities as for the size and type of industry?

Based on literature review following this introduction three hypotheses were formulated for the survey:

$\mathrm{Hl}$ : Companies which plan RL activities strategically, outsource more activities compared to those which plan reverse operations only on tactical or operational level or do not plan them at all (they manage ad hoc);

H2: Companies which plan RL activities strategically, outsource different activities compared to those which do not plan RL at all (they manager ad hoc) or only on tactical, operative level and/or ad hoc;

H3: Companies which outsource more RL activites ( 3 and more), perceive more often financial benefits than nonfinancial benefits coming from reverse flows.

The country where the survey was realized is the Czech Republic. Only few studies about RL management in this country have been realized until now and even less research have been done about RL outsourcing (Škapa and Klapalová, 2009). Therefore survey results enrich the spectrum of knowledge about reverse logistics in the context of the involvement of 3PL in this country.

The paper proceeds as follows: First, the theoretical underpinnings of the empirical survey are explained. Next the data collection and methods applied are presented. Results and discussion are introduced in following part. The final sections include the limitations of the survey, conclusions and suggestions for future research.

Logistics and within it reverse logistics belong to business areas that utilize very often the services of other parties beyond basic relations between company and its suppliers and customers. As Lieb et al. introduce (1993), there are several terms that serve as synonymous for such engagement of logistics service providers, namely outsourcing, third party logistics (3PL or TPL) and contract logistics. In 1996 another term - 4PL (fourth party logistics) emerged that can be joined to the previous ones. According the authors of 4PL term coming from the Accenture company this term means an integrator that assembles the resources, capabilities and technology of its own organisation and other organisations to design, build and run comprehensive supply chain solutions (cited in Ojala et al., 2006; p. 9). If company utilizes the services solely of such integrator, it can perform as $3 \mathrm{PL}$. In this paper $3 \mathrm{PL}$ and outsourcing will be used interchangeably.

Managerial issues and value capturing or creation are comprehend in the definition of reverse logistics: "process of planning, implementing, and controlling the efficient, cost effective flow of raw materials, in-process inventory, finished goods and related information from the point of consumption to the point of origin for the purpose of recapturing value or proper disposal (Rogers and Tibben-Lembke, 1998; p. 2). There is no standard definition of outsourcing or the engagement of the third party into business operations. For instance Barthélemy and Adsit define outsourcing very narrowly and generally as turning over all or part of an organizational activity to an outside vendor (2003; p. 87). On the contrary Bardoloi offers rather specified definition: Outsourcing is the process of procuring services or products from an external service provider with a view to curb costs, replace in-house capabilities, and thereby reduce the time period of projects. Outsourcing is thus a full transfer or delegation of an organization's facility management functions to an external firm (2004; p. 1). For managerial use the best definition is another very simple description - the concept means the abbreviation of three words "outside resource using" (Arnold, 2000; p. 23). This definition proceeds from the Resource Based View theory and despite its simplicity it enables to understand many forms of outsourcing. According to this theory, companies search for and keep "rare, nonsubstitutable, and difficult-to-copy resources and capabilities to earn above-normal rents" (Verwaal et al., 2009; p. 421) and to gain maximum value. Such resources - both tangible and intangible help companies to get sustainable competitive advantage. If companies do not own such resources for competitive value creation, they have to find external providers (Logožar, 2008).

Therefore the lack of resources ownership is one of the reasons why companies outsource, why they outsource in logistics or supply chain and why they in many cases outsource also in RL management. The question to engage or not to engage third party has to be answered within three areas: a) if 
outsourcing add value (there are hidden costs also in RL) (Lambert et al., 2011; Logožar, 2008; Pochampally et al., 2009); b) what type of value (financial or nonfinancial, where both can influence each other and this impact can be also hidden in many cases and have long-term character) and c) how much value can be got by the activity outsourced.

Other potential reasons for outsourcing which can be called as benefits found in literature can be summarized as these: reducing operating costs, cash flow improvement, elimination of infrastructure investments or reduction in capital investments, risk sharing, reduction of risks and liabilities, access to resources not available in company's internal environment and/or to the outputs of such resources if needed (e.g. know-how or best class products, services or processes) or more specified access to advanced technology and/or specialised expertise (Hilletofth and Hilmola, 2010; Persson and Virum, 2001; Belcourt, 2006), flexibility improvement in general or operational efficiency improvement, service improvement in general (Ordoobadi, 2009), customer service improvement, flexibility increase towards the changing requirements of customers, reduction of capital employed, environmental awareness increase, expansion into unfamiliar (or new) markets, differentiation from competitors (Sahay and Ramneesh Mohan, 2006), in supply chains also reduction in the complexity of logistics operations (Hilletofth and Hilmola, 2010), quality improvement, reduction of transaction time, financial savings in general, strategic focus on core competencies (Belcourt, 2006). Ordoobadi classifies reasons for outsourcing reverse flows into three categories: strategic, operational and financial (Ordoobadi, 2009).

Concentration to only financial measures of outsourcing can be considered as defensive and operational management behaviour (Bettis et al., 1992). Nevertheless, for companies strictly following cost leadership business strategy, the decision for external provider of activity that would help to improve financial performance and keep minimum level of costs is neither operational nor tactical decision, but the strategic one. Strategic dimension of outsourcing and especially in the case of reverse logistics is not always properly understood by management. However, as Quélin and Duhamel citing Grant (2002) stress, outsourcing influences the resources allocated to business units as well as the level of vertical specialisation of the firm's activities, both of which are strategic corporate decisions (2003; p. 648). In the area of reverse flows, determination of return policy which includes the decision of actors involved in reverse processes, their roles, their share on value creation for company and the potential impact on company competitive advantage must be solved at the strategic level (Lambert et al., 2011).

Any type of RL activity can be outsourced. The list of typical RL activities is introduced for instance by Rogers and Tibben-Lembke (1998), who divide activities into two groups - to product and packaging connected (returns to supplier, resale, sale via outlet, salvage, reconditioning, refurbishing, remanufacturing, reclaiming, recycling, land filling). De Brito and Dekker (2003) proposed the pyramid of recovery option which represents options of recapturing or recovery of potential value within given activities. Resale, re-use and re-distribution are at the top of the pyramid enabling to gain highest value followed by repair, refurbishing, remanufacturing, parts retrieval, recycling, incineration and land filling which is at the bottom of pyramid with negative value recovered from reverse flows. Krumwiede and Sheu (2002) and Lambert et al.(2011) present other list of reverse flows activities - much of them are the same as previous mentioned ones, the rest are synonymous: retrieval or recall (process of collecting and removing products from customers), transport, disposition (inspection, repair, rework, replacement, disassembly, salvage, liquidation sales, landfill disposal).

Concept of value capturing as one of the most important items for outsourcing decision (together with the perception of risk, need of control and investment, extent and character of complexity and/ or specificity of process determined for outsourcing etc.) is visible (more or less) also in the activities which companies or their 3PL partners provide. Activities can be assessed on the base of their position on the continuum from peripheral (or trivial or non core) through core distinct (supporting), coreclose to core for business and business success (Gilley and Rasheed, 2000; Arnold, 2000; Logožar, 2008). Although activities within reverse flows are often considered as non-core (Serrato et al., 2004) and non-generating value (Mukhopadhyay and Setaputra, 2006) and as such they are usually typical representatives for outsourcing - e.g. transport, consolidation, warehousing and freight forwarding on tactical decision level (Krumwiede and Sheu, 2002), the recent trends show the shift from outsourcing of (only) peripheral activities to outsourcing the core ones to 3 PL (Kara, 2011; Hilletofth and Hilmola, 2010; Ordoobadi, 2009) as well as the whole managerial processes to 4PL in supply chains context (Mukhopadhyay and Setaputra, 2006).

The engagement of 3PL in RL has to reflect also some specificities and/or distinct character of RL management. The most typical ones are: higher complexity of processes that demand higher expertise and specialization compared to forward flows; need for special services (e.g. parts repair and screening for refurbishment/ remanufacturing) beyond core business (Kumar and Putnam, 2008), uncertain and inconsistent extent, content and quality of flows (that requires flexible capacity requirements for storage, processing, and transportation) (Cheng and Lee, 2010; p. 1112), timing (Ordoobadi, 2009) and dependence on company size and type of industry (Kumar and Putnam, 2008; Presley et al., 2007). 


\section{MATERIALS AND METHODS}

To examine how the engagement of $3 \mathrm{PL}$ is connected to some managerial decisions in the companies operating in the Czech Republic structured questionnaire for obtaining the data and information was used. The questionnaire includes 22 questions covering also other issues of RL management beyond the topic of 3PL. The length of the questionnaire and multiple character of themes has some advantages as well as disadvantages. One of the disadvantages lead to the limitation of survey - the topic of outsourcing could not be analysed in more detail. Answers from 150 representatives from the same number of companies were collected during the winter 2010 and 2011 through personal interviews, which enabled to get answers also to the most of open questions (which are not always filled in in the case of mail or on-line surveys). Respondents were logistics or supply chain managers, in some cases marketing managers (it means professionals from the middle and the top management as well) of small, middle and big-sized enterprises from various industries and branches (commerce and service, food processing, engineering, chemical and pharmaceutical industries were those with the highest rate of responses). Concrete respondent persons were chosen on the base of previous telephone, e-mail or personal inquiry about the proper and responsible person capable to give right information.. Survey had an introductory exploratory character being the first existing survey concerning RL outsourcing management in context with other issues of RL management in this country.

Respondents were given this list of 11 activities and they were asked whether they employ or not every individual activity (dichotomy answer). Means, standard deviation, correlation (determined with a Spearman's Rho) between a) variable strategic versus nonstrategic planning and variable number of outsourced activities, b) between variable strategic versus only ad hoc decision and variable number of outsourced activities and c) between variable real reverse flows benefit (where 1 stated for financial and 2 for nonfinancial benefits) and number of outsourced activities was computed. For the same couples of variables also the independent samples tests (Levene's test for Equality of Variance and t-test for Equality of Means) and ANOVA and ANOVA post hoc Bonferroni were applied. We analysed also the dependency on size of companies (small, middle and big according the number of employees) and type of industry with 4 production industries - chemical, food processing, engineering and one group of other types not ranked into the previous three ones and one 'non production industry' commerce and services.

Although survey asked also for the reasons why company outsources every individual activity, in this paper the analysis concentrates on the link between the activities outsourced and perceived benefits (financial - nonfinancial) of RL management as such. This question was the open one, it means the answers had to be categorised and divided into two groups.

\section{RESULTS AND DISSCUSSION}

The results for the $\mathrm{Hl}$ show statistically significant relationship (at the 0.05 level) between character of planning hierarchy and number of outsourced activities. The Spearman's rho coeff. is 0.150, Sig. (1-tailed) 0.033. Mean for number of outsourced activities within strategically planning companies is 2.58 (St. deviation 1.835) whereas Mean for companies which do not plan on this top level is only 2.17 (with higher St. deviation - 2.156).

When we compare companies which plan RL on strategic level with companies which do not plan at all (they plan ad hoc), the results again confirm $\mathrm{Hl}$, but relation is not statistically significant. Mean for number of outsourced activities within companies not planning RL at all is 1.81 and Spearman's rho is -0.095 , Sig. (1-tailed) is 0.123. Both findings indicate that companies that involve RF and RL into planning processes and plans and especially into the plan that have potential higher and longer impact on the company's existence and interdependence with other areas of business make more decisions also in other areas - in this case in decisions what and how much to outsource. Although we have no proof from our survey we can make some cautious assumptions that managers that do not plan RF are probably not conscious of potential value of these flows and maybe also not able to decide if outsourcing of RF activities could be outsourced to bring even more value (at least to reduce costs).

Size of companies correlates with number of activities outsourced (Mean for number of activities outsourced and a) small companies is 2.20 , St. dev. is 2.022 , for b) middle companies the Mean is 2.34 and St. dev. is 1.881 and for c) big companies is 2.74 and St. dev. is 2.061, but this relation is not statistically significant (Spearman's rho is 0.106, Sig. 1-tailed is 0.098 ) and it can be expected - the bigger company, usually the more reverse flows and the more activities that must cope with them.

There is also dependence between the number of activities and character of industry - production industries (chemical, engineering, food processing and companies put into the category 'others') engage 3PL for more activities (N 106, Mean 2.46, St. dev. 1.948) compared to companies from commerce and services (N 44, Mean 2.25, St. dev. 2.081). Again this relation is not statistically significant - Spearman's rho is 0.70 and Sig. (1-tailed) is 0.197. If we explore individual industries, the Means for activities outsourced are: commerce and services: 2.25, chemical: 3.14 , food processing 2.67 and engineering 2.71. Chemical industry deals with many reverse flows that are environmentally dangerous and companies have to deal with these flows just for to comply with the legislative requirements. The very much common it is with food processing. 
For the $\mathrm{H} 2$ frequencies, percentage and independent samples test (Levene's Test for Equality of Variance and t-test for Equality of Means) was used. The findings indicate differences as well as statistically significant differences between the two groups of companies see Tab. I below.

There are some similarities and differences as well in the type of activities and share of their use between companies planning RL strategically and those that plan only on tactical, operative level or do not plan at all. For both groups 3PL engagement for transport belongs to the most often outsourced activity just with the difference in share in favour for companies strategically planning (67.1\% compared to $56.9 \%)$. The second biggest share concerns the same activity for both groups again - destruction, refurbishing. In this case the share is slightly more in favour for the companies which do not plan strategically (the difference is $4.3 \%$ ). Collection is the third most often used activity by both groups, but in this case companies strategically planning RL outsource this activity more often (difference in shares is $11.3 \%$ ). The fourth activity ranked same for both groups is the resale of components (or items, materials or packaging). Companies that plan RL strategically apply this activity more frequently, as well (with the difference of 12.8\%). The share and the rank of the rest of activities differ. Whereas activity selection/sorting for companies that plan RL strategically is on the fifth rank with the share of $24.7 \%$, for the other group it is ranked within one of the three the least used activities. On the contrary, reassembly/rework presents bigger share for companies not planning strategically (difference is $7.2 \%$ ). The difference of shares within two groups for selection/sorting is 15.5\%.

Results of t-test also pointed out statistically significant dependence between the variables level of planning involvement and the type of activities outsourced, namely within three types of activities: selection/sorting/separation (Sig. is 0.014), repackaging and resale (Sig. is 0.021) and resale of components/items/ materials/packaging (Sig. is 0.063) it means to be very near of statistically significance. These are activities from the top of value recovery pyramid of reverse logistics activities. This finding thus confirms that companies that plan RF strategically outsource more often activities that can bring more value when recovering the content of the flows. Outsourcing in these types of activities might be understood as understanding the potentiality of value capturing as well as the knowledge of resource and capabilities insufficiency.

Statistically significant differences of Means (at 0.05 level) on the basis of ANOVA post hoc Bonferroni test results when analysing the dependence between the size of companies and type of activity outsourced were found in the case of collection, selection and reassembly.

I: Strategic versus nonstrategic planning of RF and number of RF activities outsourced

\begin{tabular}{|c|c|c|c|c|c|c|}
\hline & $\begin{array}{l}\text { strategic (1) - nonstrategic } \\
\text { planning of RF (2) }\end{array}$ & $\mathbf{N}$ & Mean & Std. Dev. & t-test & $\begin{array}{c}\text { Sig. } \\
\text { (1-tailed) }\end{array}$ \\
\hline \multirow{2}{*}{ collection } & 1 & 85 & 0.28 & 0.453 & & \\
\hline & 2 & 65 & 0.17 & 0.378 & 1.627 & 0.106 \\
\hline \multirow{2}{*}{ purchase } & 1 & 85 & 0.08 & 0.277 & & \\
\hline & 2 & 65 & 0.08 & 0.269 & 0,121 & 0.904 \\
\hline \multirow{2}{*}{ sorting } & 1 & 85 & 0.25 & 0.434 & & \\
\hline & 2 & 65 & 0.09 & 0.292 & 2,478 & 0.014 \\
\hline \multirow{2}{*}{ transport } & 1 & 85 & 0.67 & 0.473 & & \\
\hline & 2 & 65 & 0.57 & 0.499 & 1.270 & 0.206 \\
\hline \multirow{2}{*}{ reassembly/rework } & 1 & 85 & 0.22 & 0.419 & & \\
\hline & 2 & 65 & 0.14 & 0.348 & 1.324 & 0.188 \\
\hline \multirow{2}{*}{ dismantling } & 1 & 85 & 0.08 & 0.277 & & \\
\hline & 2 & 65 & 0.15 & 0.364 & -1.368 & 0.173 \\
\hline \multirow{2}{*}{ repackaging and resale } & 1 & 85 & 0.04 & 0.186 & & \\
\hline & 2 & 65 & 0.14 & 0.348 & -2.334 & 0.021 \\
\hline \multirow{2}{*}{ warehousing } & 1 & 85 & 0.19 & 0.393 & & \\
\hline & 2 & 65 & 0.15 & 0.364 & 0.548 & 0.584 \\
\hline \multirow{2}{*}{ destruction } & 1 & 85 & 0.39 & 0.490 & & \\
\hline & 2 & 65 & 0.43 & 0.499 & -5.222 & 0.602 \\
\hline \multirow{2}{*}{ charity } & 1 & 85 & 0.09 & 0.294 & & \\
\hline & 2 & 65 & 0.09 & 0.292 & 0.038 & 0.970 \\
\hline \multirow{2}{*}{ resale of components } & 1 & 85 & 0.28 & 0.453 & & \\
\hline & 2 & 65 & 0.15 & 0.364 & 1.872 & 0.063 \\
\hline
\end{tabular}


The results show that within collection and selection/sorting the share of companies which provide these activities is higher with middle and big companies. On the contrary, the share for the activity of reassembly is higher with middle and small companies.

There are also differences among individual industries and type of activities outsourced. While for instance transport of RF is outsourced by 92.9\% of companies from chemical industry, only $56.8 \%$ of companies from commerce and services outsource this activity. Collection is outsourced by $33.3 \%$ companies from engineering industry, but by no of companies from food processing. The same we can say about selection (also the share is same). Destruction or refurbishing is outsourced mostly by food processing companies (66.7\%) and the least by commerce and services (36.4\%). Food processing industry has the highest share of companies which outsource charity as RF (33.3\%) compared to engineering industry with the smallest share (4.4\%). Resale of components/items/materials/packaging is outsourced most often by companies from chemical industry (42.9\%), while commerce and services do not outsource such activity very often (11.4\%).

The third hypothesis is based on the presumption that the level of outsourcing involvement is related to the level of resources allocated to the processes connected to outsourcing and working with hard data can be linked to the higher level of understanding which value categories may be inherent in outsourcing. The issue of the character of benefits was examined through one open question asking which value does the company retrieves from RL. All statements were coded into categories of value and after divided into financial benefits, nonfinancial benefits and costs.

The results of the analysis indicate that the $\mathrm{H} 3$ must be rejected. The higher number of activities outsourced, the higher number of perceived nonfinancial benefits were introduced by the respondents. 52 companies perceive financial benefits (from 1 to 3 maximum, e.g. higher profit, higher turnover, cost decrease...) and 90 companies perceive nonfinancial benefits (from 1 to 4 maximum - e.g.customer satisfaction, image, information received from RL etc.), 24 companies perceive (also) the sacrifices of RL (in the form of financial costs). Mean for financial benefits perceived by companies that outsource 3 and more activities is 1.27 (St. deviation is 0.533) and Mean for nonfinancial benefits is 1.62 (St. deviation is
0.834). Spearman's rho for number of outsourced activities and a) number of financial benefits is 0.169 and b) number of nonfinancial benefits is $=0.024$ with no statistical significance. To understand the context of these findings several data of companies' performance would be needed, for instance for answering the question if companies that outsource more activities and perceive more nonfinancial benefits are more or less successful in comparison to the other group of companies. Otherwise we can just speculate that companies that outsource more activities and at the same time perceived more nonfinancial benefits: a) do not measure financial impact of reverse flows and/or outsourcing the activities connected to reverse flows; b) just on the contrary, they measure financial impact of RF and outsourcing and they are just simply conscious of other benefits than just financial.

Significant dependence was detected between the size of company and number of both benefits perceived with RL. Sig. of Levene's Test for Eq. of Var. for number of financial benefits is 0.00, Sig. (2-tailed) with $p$-value of t-test $=0.094$ and for number of nonfinancial benefits is Sig. of Levene's Test 0.024 and Sig. (2-tailed) with p-value of t-test $=0.359$. Mean for number of financial benefits in the case of small companies is 1.11, for middle companies is 1.22 and for big companies 1.44, Mean for number of nonfinancial benefits in the case of small companies is 1.52 , for middle companies is 1.57 and for big companies is 1.70. Managers of big companies are able introduce more categories of both groups of benefits.

The final results concern the analysis of the relation between type of industry and type of value perceived and they imply several differences among industries. Although representatives of all industries introduce most often nonfinancial benefits, the biggest share (if we do omit "other") can be found within commerce and services (65.7\%) and chemical industry (66.7\%), the smallest within food processing industry (25.8\%). Companies from this industry mentioned slightly more often costs (as the negative side of value) ( $12.9 \%$ compared to $5.0 \%$ engineering, 8.6\% commerce and services), whereas no company from chemical industry mentioned costs. Higher share compared to the other industries in the case of only or more given financial benefits can be found with engineering industry $130.0 \%$ compared to food processing - $25.8 \%$, chemical $11.1 \%$ or commerce and services $-5.7 \%)$.

\section{CONCLUSIONS}

When summarizing the findings for the hypotheses testing, $\mathrm{Hl}$ and $\mathrm{H} 2$ were confirmed (also with statistically significant differences between investigated and expected differences. In the case of $\mathrm{HI}$ there is significant (statistically) relationship between level of planning involvement in the case of reverse flows planning and the number of RF outsourced. Companies that plan these flows on the strategic level use services of 3PL for more activities within reverse logistics in comparison with those companies that do not plan reverse flows at all. Conclusions for $\mathrm{H} 2$ show that companies that plan RF 
strategically either outsource more frequently different RL activities or (if the ranking of some of 11 surveyed activities is same) the share of activities is different. It is in the case of transport, collection and resale when the share is higher for those that plan RL strategically and in case of destruction when the share is higher for those that do not plan RL at all.

The H3 must be rejected. The findings show just the opposite relation when the higher number of activities outsourced, the higher number of perceived nonfinancial benefits were introduced by the respondents.

The results of survey confirm and supplement existing empirical knowledge with strategic character of RL outsourcing management. The main findings prove that strategic planning is connected to:

1. outsourcing of more activities (nevertheless there can be dependence with the size of companies);

2. the fact that such companies outsource different activities or the share of different outsourced activities vary;

3. activities that are outsourced distinctly more by the companies planning RL strategically belong to the activities creating higher value for companies (according to De Brito and Dekker pyramid (see Literature Review). This is the case of resale of components, items/parts/packaging and collection and selection/sorting. Final two activities are not covered in the pyramid, but they are precondition for the resale that is at the top of pyramid. From 34 companies which plan RL strategically and resale the parts/item, 11 outsource collection and 7 sorting/selection activities.

Findings also discover that companies that are more involved in RL outsourcing perceive more benefits (and less costs) and more nonfinancial benefits compared to financial benefits. In the connection with this result one question can be formulated: "Which companies outsource more RF?" that can be solved in further research in the context of several potential answers: a) those companies that do not have enough resources (how it is with their competitiveness and quality of planning processes?); b) companies that focus on their core competencies or c) companies that focus on costs and the management expect to save money by outsourcing RF. This is the question of performance management and measurement.

The survey has several limitations. First the multiple and multi-topics covering questionnaire did not enable to explore the issues of outsourcing deeper and in another interesting context. Number of respondents is not enough big to formulate any general conclusions and no generalisation can be done for the findings concerning industries, as well.

\section{REFERENCES}

ARNOLD, A., 2000: New dimensions of outsourcing: a combination of transaction cost economics and the core competencies concept, European Journal of Purchasing \& Supply Management, 6, 1: 23-29. ISSN 0969-7012.

BARTHELÉMY, J. and ADSIT, D., 2003: The Seven Deadly Sins of Outsourcing [and Executive Commentary], The Academy of Management Executive, 17, 2: 87-100. ISSN 0896-3789.

BARDOLOI, S., 2004: Outsourcing + Insourcing Key to Smartsourcing, Pinnacle Research Group, Pinnacle Systeme. Available at: <http://www.altechnology. com/blog/Outsourcing/2004_03_22_outsourcing. htm $>$.

BELCOURT, M., 2006: Outsourcing - the benefits and the risks, Human Resource Management Review, 16, 2: 269-279. ISSN 1853-4822.

BETTIS, R. A., BRADLEY, S. P. and HAMEL, G., 1992: Outsourcing and Industrial Decline, The Executive, 6, 1: 7-22. ISSN 1938-9779.

DE BRITO, M. P., 2003: Managing reverse logistics or reversing logistics management, ERIM Ph.D. Series Research in Management, 35, Erasmus University Rotterdam. pp. 327. ISBN 90-5892-058-6.

DEBRITO, M.P. and DEKKER, R., 2003: Aframework for reverse logistics, ERS-2003-045-LIS, ERIM, Erasmus University Rotterdam. pp. 29.
CHENG, Y. H. and LEE, F., 2010: Outsourcing reverse logistics of high-tech manufacturing firms by using a systematic decision-making approach: TFT-LCD sector in Taiwan, Industrial Marketing Management, 39, 7: 1111-1119. ISSN 0019-8501.

HILLETOFTH, P. and HILMOLA, O.-P., 2010: Role of logistics outsourcing on supply chain strategy and management. Survey findings from Northern Europe, Strategic Outsourcing: An International Journal, 3, 1: 46-66. ISSN 1753-8297.

GILLEY, K. M. and RASHEED, A., 2000: Making More by Doing Less: An Analysis of Outsourcing and its Effects on Firm, Journal of Management, 26, 4: 763-790. ISSN 1557-1211.

KAKABADSE, A. and KAKABADSE, N., 2002: Trends in Outsourcing: Contrasting USA and Europe, European Management Journal, 20, 2: 189198. ISSN 0263-2373.

KARA, S. S., 2011: Evaluation of outsourcing companies of waste electrical and electronic equipment recycling, International Journal of Environmental Science and Technology, 8, 2: 291-304. ISSN 1735-2630.

KRUMWIEDE, D. W. and SHEU, C., 2002: A model of reverse logistics entry by third-party providers, Omega, 30, 5: 325-333. ISSN 0305-0483.

KUMAR, S. and PUTNAM, V., 2008: Cradle to cradle: Reverse logistics strategies and opportunities across three industry sectors, International Journal 
of Production Economics, 115, 2: 305-315. ISSN 09255273.

LAMBERT, S., RIOPEL, D. and ANDUL-KADER, W., 2011: A reverse logistics decisions conceptual framework, Computers \& Industrial Engineering, 61, 3: 561-581. ISSN 0360-8352.

LIEB, R. C., MILLER, R. A. and WASSENHOVE, L. N. V., 1993: Third party logistics services: a comparison of experienced American and European manufacturers, International Journal of Physical Distribution and Logistics Management, 23, 6: 35-44. ISSN 0960-0035.

LOGOŽAR, K., 2008: Outsourcing Reverse Logistics, Zagreb International Review of Economics \& Business, 11, 2: 35-45. ISSN 1331-5609.

MOLLENKOPF, D. A. and CLOSS, D. J., 2005: The hidden value in reverse logistics, Supply Chain Management Review, 5, 7/8: 34-43. ISSN 1521-9747.

MUKHOPADHYAY, S. K. and SETAPUTRA, R., 2006: The role of 4PL as the reverse logistics integrator. Optimal pricing and return policies, International Journal of Physical Distribution \& Logistics Management, 36, 9: 716-729. ISSN 0960-0035.

ORDOOBADI, S. M., 2009: Outsourcing reverse logistics and remanufacturing functions: a conceptual strategic model, Management Research News, 32, 9: 831-845. ISSN 0140-9174.

PERSSON, G. and VIRUM, H., 2001: Growth Strategies for Logistics Service Providers: A Case Study, International Journal of Logistics Management, 12, 1: 53-64. ISSN 0957-4093.

POCHAMPALLY, K. K., GUPTA, S. M. and GOVINDAN, K., 2009: Metrics for performance measurement of a reverse/closed-loop supply chain, International Journal of Business Performance and Supply Chain Modelling, 1, 1: 8-32. ISSN 1758941X.

PRESLEY, A., MEADE, L. and SARKIS, J., 2007: A Strategic Sustainability Justification
Methodology for Organisational Decisions: A Reverse Logistics Illustration, International Journal of Production Research, 45, 18-19: 4595-4620. ISSN 1366-588X.

OJALA, L., ANDERSSON, D. and NAULA, T., 2006: The definition and market size of the third party logistics services. pp. 7-26. In: OJALA, L. and JÄMSÄ, P (eds.), Third party logistics-Finnish and Swedish experiences. Series Discussion and Working Papers. Turku: Turku School of Economics). pp. 138. ISBN 951-564-362-7.

ROGERS, D. S. and TIBBEN-LEMBKE R., 1999: Going backwards: reverse logistics trends and practices, Pittsburgh: Reverse Logistics Executive Council. pp. 283. ISBN 0-9674619-0-1.

QUELIN, B. and DUHAMEL, F., 2003: Bringing Together Strategic Outsourcing and Corporate Strategy: Outsourcing Motives and Risks, European Management Journal, 21, 5: 647-661. ISSN 02632373.

SAHAY, B. S. and RAMNEESH MOHAN, 2006: 3PL practices: an Indian perspective, International Journal of Physical Distribution \& Logistics Management, 36, 9: 666-689. ISSN 0960-0035.

SERRATO, M, RYAN, S. M. and GAYTAN, J., 2004: Characterization of reverse logistics network for outsourcing decisions. Available at: <www.public. iastate.edu/ smryan/msrevlog.pdf $>$.

ŠKAPA, R. and KLAPALOVÁ, A., 2000: Reverse Logistics in the Czech Republic: Outcomes of the Preliminary Research, ICABR 2009, Brno: MZLU, pp. 11. ISBN 90-5892-058-6.

VERWAAL, E., COMMANDEUR, H. and VERBEKE, W., 2009: Value Creation and Value Claiming in Strategic Outsourcing Decisions: A resource contingency perspective, Journal of Management, 35 , 2: 420-444. ISSN 1557-1211.

Address

Ing. Alena Klapalová, MSc., Ph.D., Masarykova univerzita, Ekonomicko-správní fakulta, Katedra podnikového hospodářství, Lipová 4la, 60200 Brno, Česká republika, klapalov@econ.muni.cz 